\title{
Parameterization of convective transport in the boundary layer and its impact on the representation of the diurnal cycle of wind and dust emissions
}

\author{
F. Hourdin ${ }^{1}$, M. Gueye ${ }^{2}$, B. Diallo ${ }^{1}$, J.-L. Dufresne ${ }^{1}$, J. Escribano ${ }^{1}$, L. Menut ${ }^{1}$, B. Marticoréna ${ }^{3}$, G. Siour ${ }^{3}$, and \\ F. Guichard ${ }^{4}$ \\ ${ }^{1}$ Laboratoire de Météorologie Dynamique, CNRS/IPSL/UMPC, Paris, France \\ ${ }^{2}$ LPAOSF, UCAD, Dakar, Sénégal \\ ${ }^{3}$ LISA, UMR CNRS 7583, UPEC, UPD, IPSL, Créteil, France \\ ${ }^{4}$ CNRM-GAME, UMR CNRS 3589, Météo France, Toulouse, France
}

Correspondence to: F. Hourdin (hourdin@1md.jussieu.fr)

Received: 16 August 2014 - Published in Atmos. Chem. Phys. Discuss.: 31 October 2014

Revised: 18 February 2015 - Accepted: 07 April 2015 - Published: 18 June 2015

\begin{abstract}
We investigate how the representation of the boundary layer in a climate model impacts the representation of the near-surface wind and dust emission, with a focus on the Sahel/Sahara region. We show that the combination of vertical turbulent diffusion with a representation of the thermal cells of the convective boundary layer by a mass flux scheme leads to realistic representation of the diurnal cycle of wind in spring, with a maximum near-surface wind in the morning. This maximum occurs when the thermal plumes reach the low-level jet that forms during the night at a few hundred meters above surface. The horizontal momentum in the jet is transported downward to the surface by compensating subsidence around thermal plumes in typically less than $1 \mathrm{~h}$. This leads to a rapid increase of wind speed at surface and therefore of dust emissions owing to the strong nonlinearity of emission laws. The numerical experiments are performed with a zoomed and nudged configuration of the LMDZ general circulation model coupled to the emission module of the CHIMERE chemistry transport model, in which winds are relaxed toward that of the ERA-Interim reanalyses. The new set of parameterizations leads to a strong improvement of the representation of the diurnal cycle of wind when compared to a previous version of LMDZ as well as to the reanalyses used for nudging themselves. It also generates dust emissions in better agreement with current estimates, but the aerosol optical thickness is still significantly underestimated.
\end{abstract}

\section{Introduction}

Desert dust is a secondary but significant contributor to atmospheric radiative transfer, with regional signatures dominated by desert areas like North Africa, which is estimated to contribute $25-50 \%$ of the global dust emissions (Engelstaedter et al., 2006). This change in radiation may affect the largescale circulation by inducing regional contrasts of several tens of $\mathrm{W} \mathrm{m}^{-2}$ (Yoshioka et al., 2007; Solmon et al., 2008; Spyrou et al., 2013), as well as the convective processes in the atmosphere through modulation of the atmospheric static stability. Dust is more and more often taken into account interactively in global climate simulations, such as those coordinated at an international level in the Coupled Model Intercomparison Project (CMIP, Taylor et al., 2012) on which future climate change estimates are based. Dust is a tracer of atmospheric motions that sediments into the atmosphere and can be deposited to the surface rapidly and washed out by rainfall. One of the important and uncertain dust-related processes is emission, which depends nonlinearly on the friction velocity $U^{*}$ (Gillette, 1977; Nickling and Gillies, 1989, 1993; Gomes et al., 2003; Rajot et al., 2003; Sow et al., 2009; Shao et al., 2011).

The emission thus depends on the tail of the near-surface wind distribution than on the wind mean value. During winter and spring, dust emissions largely occurs in the morning (see e.g., Schepanski et al., 2009), which coincides with the daily maximum wind speed in the observations in the $\mathrm{Sa}$ - 
hel (Parker et al., 2005; Lothon et al., 2008; Guichard et al., 2009; Schepanski et al., 2009). This maximum is associated with the low-level jet which forms at a few hundred meters above the surface after sunset, when the near-surface boundary layer turbulence collapses (see e.g., Bain et al., 2010; Gounou et al., 2012; Fiedler et al., 2013). After sunrise, a convective boundary layer rapidly develops, which brings momentum from this low-level jet down to the surface and further mixes horizontal momentum over the depth of the convective boundary layer, typically 2 to $6 \mathrm{~km}$ thick over Sahara and Sahel (see e.g., Cuesta et al., 2009). Todd et al. (2008) report problems in the representation of the diurnal cycle of near-surface wind in a series of simulations with regional models over the Bodélé region during the Bodex 2005 experiment. They also conclude that the problem comes more from missing physics in the model than from the grid resolution. This diurnal cycle is neither well captured in the ERA-Interim (ERAI) reanalyses (Fiedler et al., 2013) nor in other state-of-the-art reanalysis data sets as recently shown by Largeron et al. (2015). Fiedler et al. (2013) report typical underestimation of $24-50 \%$ for the jet maximum velocity in the Bodélé region. Todd et al. (2008) and Knippertz and Todd (2012) underline the importance of a good representation of the contrast between nocturnal turbulence in a stable atmosphere and convective transport during the day for the representation of this nocturnal jet and its impact on surface wind.

Various approaches have been proposed in the past decades to represent boundary layer convection. Deardorff (1970) first noticed that parameterizations of boundary layer turbulence that are based on eddy or $K$ diffusion fail to represent the basics of boundary layer convection, which essentially transports heat upward from the surface. This corresponds to upgradient transport of potential temperature since the atmosphere is generally neutral or even slightly stable in the so-called "mixed layer" (typically several kilometers thick in this region of the globe in the afternoon), above the unstable surface layer (typically a few hundred meters thick). The counter-gradient term he proposed to reconcile the diffusive formulations with convection conditions was later given a more explicit formulation based on the non-local aspect of convective transport by Troen and Mahrt (1986) and by Holtslag and Boville (1993). Stull (1984) underlined the importance of non-local aspects and proposed the "transilience matrices" framework. Chatfield and Brost (1987) first proposed combining a diffusive approach with a "mass flux" scheme dedicated to the representation of the boundary layer convection. In this approach, the convection is represented by splitting the atmospheric column in two compartments: one associated with the concentrated buoyant updrafts (or thermal plumes) that rise from the surface and the other one with compensating subsidence around those plumes. This approach was developed independently by two teams and since adopted in several groups (Hourdin et al., 2002; Soares et al., 2004; Siebesma et al., 2007; Pergaud et al., 2009; Angevine et al., 2010; Neggers et al., 2009; Neggers, 2009; Hourdin et al., 2013b). It has been shown in particular to open the way to quite accurate representation of cumulus clouds that form at the top of convective thermal plumes (Rio and Hourdin, 2008; Jam et al., 2013). The first application of these ideas to the simulation of the dry convective boundary layer (Hourdin et al., 2002) demonstrated the capability of the so-called "thermal plume model" to correctly represent the up-gradient transport of heat in a slightly stable convective mixed layer. This approach was shown to also capture well the typical diurnal cycle over land, contrasting a thin nocturnal boundary layer dominated by wind shear-driven turbulent diffusion, and daily conditions in which the role of the parameterized turbulent diffusion is confined to the unstable surface layer while the mass flux scheme accounts for most of the turbulent transport in the mixed layer. This thermal plume model was developed for the LMDZ atmospheric general circulation model, in which it was activated in particular to perform a subset of climate simulations for the last CMIP5 exercise (Hourdin et al., 2013b).

The present study aims at exploring the impact of the above described parameterizations on the representation of dust emission and transport and at anticipating future versions of the climate simulations with interactive aerosols. For this, the emission module from the chemistry transport model CHIMERE (Menut et al., 2013) was coupled to the climate model. We show here how the activation of the thermal plume model leads to a better representation of the diurnal cycle of near-surface winds - even better than in current meteorological reanalyses - and how this better representation reinforces surface emissions drastically. We focus here on emissions during the dry season while a companion paper will be devoted to the representation of dust emission by gusts associated with convection-generated cold pools, for which a specific parameterization has also been introduced in LMDZ (Grandpeix and Lafore, 2010; Rio et al., 2009).

In Sect. 2 we present the numerical model and observations. We then illustrate the impact of the parameterization of the boundary layer on the near-surface wind distribution and dust emission using online dust simulations with two versions of the LMDZ physical package (Sect. 3) and compare the results with site observations (Sect. 4), before analyzing in more detail the representation of the mean diurnal cycle of near-surface wind over the Sahel when the thermal plume model is activated (Sect. 5) and drawing some conclusions.

\section{Methods}

\subsection{LMDZ5 and IPSL-CM5}

The LMDZ dynamical core is based on a mixed finite difference/finite volume discretization of the primitive equations of meteorology (approximate form of the conservation laws for air mass, momentum and potential temperature, under hy- 
drostatic and "thin layer" approximation) and conservation equations for trace species. It is coupled to a set of physical parameterizations. Two versions of the model, LMDZ5A and LMDZ5B, are considered here that differ by the activation of a different set of parameterizations for turbulence, convection and clouds. In the "Standard Physics" package (SP) used in version LMDZ5A (Hourdin et al., 2013a), boundary layer turbulence is parameterized as a diffusion with an eddy diffusivity that depends on the local Richardson number. A counter-gradient term on potential temperature (Deardorff, 1972) as well as a dry convective adjustment are added to handle dry convection cases which often prevail in the boundary layer. In the "New Physics" package (NP) of version LMDZ5B (Hourdin et al., 2013b), the vertical transport in the boundary layer relies on the combination of a classical parameterization of turbulent diffusion with the thermal plume model described below (Hourdin et al., 2002; Rio and Hourdin, 2008). The SP and NP versions also differ by the representation of deep convection closure and triggering. However, we will concentrate the present study on the dry season over West Africa when deep convection does not activate. The two versions correspond to the IPSL-CM5A and CM5B versions of the IPSL coupled model used for CMIP5 (Dufresne et al., 2013).

\subsection{The "thermal plume model"}

In the NP version, eddy diffusivity $K_{z}$ is computed based on a prognostic equation for the turbulent kinetic energy that follows Yamada (1983). It is mainly active in practice in the surface boundary layer, typically in the first few hundred meters above surface. It is combined with a mass flux scheme that represents an ensemble of coherent ascending thermal plumes as a mean plume. A model column is separated in two parts: the thermal plume and its environment. The vertical mass flux in the plume $f_{\text {th }}=\rho \alpha_{\text {th }} w_{\text {th }}-$ where $\rho$ is the air density, $w_{\text {th }}$ the vertical velocity in the plume and $\alpha_{\text {th }}$ its fractional coverage - varies vertically as a function of lateral entrainment $e_{\text {th }}$ (from environment to the plume) and detrainment $d_{\text {th }}$ (from the plume to the environment). For a scalar quantity $q$ (total water, potential temperatures, chemical species, aerosols), the vertical transport by the thermal plume reads

$$
\frac{\partial f_{\mathrm{th}} q_{\mathrm{th}}}{\partial z}=e_{\mathrm{th}} \bar{q}-d_{\mathrm{th}} q_{\mathrm{th}},
$$

where $q_{\mathrm{th}}$ is the concentration of $q$ inside the plume. Note that this formulation assumes stationarity of the plume properties when compared to the timescale of the change in the explicit model state variables $\bar{q}$, a classical approximation in mass flux parameterizations of convective motions. Here air is assumed to enter the plume with the mean grid cell concentration $\bar{q}$, which is equivalent to neglecting the plume fraction $\alpha_{\text {th }}$ in this part of the computation. This approximation is generally considered as obvious for cumulus convection, which often covers a very small fraction of the horizontal surface (e.g., Tiedtke, 1989). It is more questionable for the boundary layer convection where the fraction is often close to $5-10 \%$ but the approximation is generally maintained for numerical reasons ${ }^{1}$. The approximation is, however, probably less an issue than the specification of $e$ and $d$ and does not prevent accurate comparison with large eddy simulations (Hourdin et al., 2002).

The particular case of $q \equiv q_{\text {th }} \equiv 1$ gives the continuity equation that relates $e_{\mathrm{th}}, d_{\mathrm{th}}$ and $f_{\mathrm{th}}$. The vertical velocity $w_{\text {th }}$ in the plume is driven by the plume buoyancy $g\left(\theta_{\mathrm{th}}-\bar{\theta}\right) / \bar{\theta}$, where $\bar{\theta}$ is the mean potential temperature in the grid box and $\theta_{\text {th }}$ the potential temperature within the thermal plume at the same model level. The computation of $w_{\mathrm{th}}, \alpha_{\mathrm{th}}, e_{\mathrm{th}}$ and $d_{\mathrm{th}}$ is a critical part of the code. We use here the version of the scheme described by Rio et al. (2010) and used in LMDZ5B (Hourdin et al., 2013b). In this version, air is entrained into (detrained from) the plume as a function of the buoyancy of plume air parcels divided by the square of the vertical velocity when this buoyancy is positive (negative). Entrainment is strong near the surface, where it feeds the plume. Then detrainment is strong at the top of the mixed layer, when the plume decelerates. Entrainment can be active again above cloud base for cloud-topped boundary layers when cumulus clouds are buoyant. The plume air is then detrained close to the top of the cloud. Entrainment and detrainment rates also depend on $\alpha_{\text {th }}$. The vertical velocity is computed with the plume equation (Eq. 1) with additional buoyancy and drag terms on the right-hand side. The plume fraction is calculated as the ratio of the $f$ and $\rho w_{\text {th }}$.

Finally, for both the SP and NP versions the time evolution of $q$ reads

$\frac{\partial \bar{q}}{\partial t}=-\frac{1}{\rho} \frac{\partial \overline{\rho w^{\prime} q^{\prime}}}{\partial z}$,

with

$\overline{\rho w^{\prime} q^{\prime}}=f_{\mathrm{th}}\left(q_{\mathrm{th}}-\bar{q}\right)-\rho K_{z}\left(\frac{\partial \bar{q}}{\partial z}-\Gamma\right)$.

In the SP version, $f_{\text {th }} \equiv 0$, the computation of $K_{z}$ is based on a steady-state solution of the evolution equation of the turbulent kinetic energy (TKE), which leads to a Richardson dependent formulation, while the counter-gradient $\Gamma$ is intro-

\footnotetext{
${ }^{1}$ Abandoning the hypothesis of stationarity of the plume would imply adding a new state variable for each tracer (the tracer concentration inside the plume for instance). Abandoning the $\alpha \ll 1$ approximation would consist of replacing the term $e_{\mathrm{th}} \bar{q}$ in Eq. (1) with $e_{\mathrm{th}} q_{\mathrm{env}}$, where the tracer concentration in the plume environment $q_{\mathrm{env}}$ is given by $\bar{q}=\alpha_{\mathrm{th}} q_{\mathrm{th}}+\left(1-\alpha_{\mathrm{th}}\right) q_{\mathrm{env}}$. When, at the beginning of a time step, there is a tracer in the first model layer only ( $\bar{q}=0$ above), the concentration in the plume will be nonzero above this first layer, which would lead (because $\bar{q}=0$ ) to $q_{\mathrm{env}}=$ $\alpha_{\mathrm{th}} q_{\mathrm{th}} /\left(\alpha_{\mathrm{th}}-1\right)<0$ and may at the end result in spurious negative tracer concentrations.
} 
duced for transport of potential temperature. In the NP version, $\Gamma \equiv 0, K_{z}$ is computed from a TKE prognostic equation and $f_{\text {th }}$ accounts for the thermal plumes.

The same equation is applied for the time evolution of the horizontal component of the specific momentum $u$ and $v$ but with an optional additional term in the plume equation that accounts for the exchange of momentum by pressure torque following Hourdin et al. (2002). This optional term has a very minor impact on the results and is not activated in the present simulations for the sake of simplicity.

\subsection{The CHIMERE dust emission module}

Mineral dust injection in the atmosphere is computed using CHIMERE emission modules (Menut et al., 2013). The configuration is the one used in Menut et al. (2009) for the AMMA (African Monsoon Multidisciplinary Analysis) experiment. Dust emissions depend on the soil and surface properties and on the near-surface meteorology with the friction velocity. Soil and surface properties are issued from a $1^{\circ} \times 1^{\circ}$ database that covers North Africa, including Sahara and Sahel, available at http://www.lisa.u-pec.fr/mod/ data/index.php. The saltation flux is estimated following the Marticorena and Bergametti (1995a) scheme (see also Marticorena et al., 1997; Callot et al., 2000). Experiments indicate that the vertical dust emissions flux can be considered as a fraction of the "saltation" flux, i.e., the amount of soil material in horizontal movement at the soil surface. The saltation flux can be expressed as a function of a threshold $U_{\mathrm{Th}}^{*}$ and a cubic dependency of the wind friction velocity of the form

$F_{h}=\frac{K \rho_{a}}{g} U^{* 3}\left(1-\frac{U_{\mathrm{Th}}^{*}}{U^{*}}\right)\left(1+\frac{U_{\mathrm{Th}}^{*}}{U^{*}}\right)^{2}$

according to the work of Marticorena and Bergametti (1995b), where $K$ is a constant of proportionality which is set to $K=1$ in this work, as is recommended by Gomes et al. (2003). The vertical flux associated with sandblasting is computed with the Alfaro and Gomes (2001) scheme, optimized following Menut et al. (2005). The threshold for the friction velocity is estimated using the Shao and $\mathrm{Lu}$ (2000) scheme. In order to account for subgrid-scale variability of the mean wind speed, a Weibull distribution is used (Cakmur et al., 2004) with the following probability density function:

$p(u)=\frac{k}{A}\left(\frac{u}{A}\right)^{k-1} \exp \left[-\left(\frac{u}{A}\right)^{k}\right]$

where $u$ is the sub-grid wind speed, the shape parameter $k$ is set to $k=3$ and $A$ is calculated in order to fit the first moment of the Weibull distribution with the mean wind, i.e., $U=A \Gamma(1+1 / k)$ with $\Gamma$ the Gamma function. The sub-grid wind distribution has been discretized in 12 wind bins.

The coupling of LMDZ with the CHIMERE emission module is done similarly to the standard method used to force CHIMERE by regional climate models. The $10 \mathrm{~m}$ height wind, $U_{10 \mathrm{~m}}$, computed by LMDZ is passed to the CHIMERE emission module. Optionally, an effective wind $U_{\text {eff }}$ can be used instead. Following Beljaars and Viterbo (1994), this effective wind is computed by adding a convective vertical velocity $W^{*}, U_{\text {eff }}^{2}=U_{10 \mathrm{~m}}^{2}+W^{* 2}$, that aims to account for the wind gustiness in a statistically unstable atmosphere. This option was not activated in the simulations presented here. Its activation only marginally enhances emissions during the dry season. The same Weibull distribution as in Chimere is used for both the SP and NP versions.

The diameter of emitted dust particles ranges typically from a few nanometers to micrometers. In order to accurately describe this size distribution both in number of particles and in mass, it is common to use a discretization in size that follows a logarithmic law (Seinfeld and Pandis, 1998). For specific studies on emissions and transport of mineral dust, it has been shown that 12 bins is a good compromise between accuracy and computational cost for long-range transport model simulations (Forêt et al., 2006; Menut et al., 2007). The boundaries for the 12 dust bins used here are $0.09,0.19$, $0.67,1.49,2.27,3.46,4.81,5.58,6.79,12.99,26.64,41.60$ and $63.0 \mu \mathrm{m}$. Settling of dust particles and dry deposition are computed as in CHIMERE (Menut et al., 2013). Scavenging is also activated in the model but is not involved in the results presented here, before the monsoon onset.

\subsection{Model configuration and simulations}

In order to assess the representation of emission and turbulent processes, the model simulations are conducted with the zooming capability in a nudged mode. The use of the zoomed/nudged version for model evaluation was described in detail by Coindreau et al. (2007).

The zoom consists of a refinement of the global grid discretization in both longitude and latitude, here over West Africa and the tropical Atlantic ocean. In order to limit interpolation issues for soil properties, the zoom was chosen so as to obtain a quasi-uniform $1^{\circ} \times 1^{\circ}$ resolution over a $\left(70^{\circ} \mathrm{W}-30^{\circ} \mathrm{E}, 10^{\circ} \mathrm{S}-40^{\circ} \mathrm{N}\right)$ longitude-latitude box, close to the CHIMERE data set resolution. Nevertheless, the points of the LMDZ grid do not exactly match those of the CHIMERE dust model. First tests have shown that a linear interpolation considerably degrades the results. A nearest-neighbor method was implemented instead that provides much better results.

The LMDZ model is most commonly used in climate mode meaning it is integrated from an initial state with imposition of some boundary conditions such as insolation, sea surface temperature (in stand-alone atmospheric configurations) and composition of dry air. For validation of subcomponents of the model as is the case here, it can be desirable to force the model to follow the observed synoptic meteorological situation by nudging (relaxing) the model meteorology toward reanalysis. That way, errors coming from the deficiencies of the subcomponent can be distinguished 
from those that arise from the erroneous representation of the atmospheric circulation in the model. This also allows a direct day-by-day comparison with observations as illustrated by Coindreau et al. (2007). In practice here, winds are relaxed toward ERAI reanalyses of the European Centre for Medium-Range Weather Forecasts (ECMWF) by adding a nonphysical relaxation term to the model equations:

$$
\frac{\partial X}{\partial t}=F(X)+\frac{X^{a}-X}{\tau},
$$

where $X$ stands for $u$ and $v$ wind components, $X^{a}$ is their values in the reanalyses, $F$ is the operator describing the dynamical and physical processes that determine the evolution of $X$ and $\tau$ is the time constant.

Before applying relaxation, ERAI data are interpolated on the horizontal stretched grid of the LMDZ model as well as on the hybrid $\sigma-p$ vertical coordinates. Also, at each model time step the ERAI data are interpolated linearly in time between two consecutive states, available each $6 \mathrm{~h}$ in the data set used here. Different time constants can be used inside and outside the zoomed region (with a smooth transition between the inner and outer regions that follows the grid cell size). Here, the constant outside the zoom is $3 \mathrm{~h}$. Inside the zoom tests were made with values ranging from 1 to $120 \mathrm{~h}$. The longer the time constant, the weaker the constraint by the analyzed wind fields. We focus here on simulations with $\tau=3 \mathrm{~h}$, named SP3 and NP3 depending on the physical package used, as well as on a sensitivity test NP48 run with the NP version and $\tau=48 \mathrm{~h}$. The initial state of the simulations is taken from a multi-annual spin-up simulation with interactive dust that corresponds to 1 November 2005. The three simulations cover the years 2006 and 2007 but only the months of the dry season, from November to April, are analyzed here.

\subsection{In situ observations}

In the framework of the AMMA international project ( $\mathrm{Re}$ delsperger et al., 2006), a set of three stations, the socalled "Sahelian Dust Transect" (http://www.lisa.u-pec.fr/ SDT/), were deployed in 2006 to monitor the mineral dust content over West Africa. As described in Marticorena et al. (2010), the three stations, M'Bour (Senegal, $14.39^{\circ} \mathrm{N}$, $16.96^{\circ} \mathrm{W}$ ), Cinzana (Mali, $13.28^{\circ} \mathrm{N}, 5.93^{\circ} \mathrm{W}$ ) and Banizoumbou (Niger, $13.54^{\circ} \mathrm{N}, 2.66^{\circ} \mathrm{E}$ ), are almost aligned around $13-14^{\circ} \mathrm{N}$ on the main pathway of Saharan and Sahelian dust toward the Atlantic Ocean. They are located in the semi-arid Sahel, and the annual mean precipitation is $496 \mathrm{~mm}$ in Banizoumbou, $715 \mathrm{~mm}$ in Cinzana and $511 \mathrm{~mm}$ in M'Bour for the period 2006-2010. In Senegal, instruments are located in the geophysical station of the Institut de Recherche pour le Développement, south of the city of M'Bour, about $85 \mathrm{~km}$ from Dakar. The instruments are installed at $\sim 10 \mathrm{~m}$ height, on the roof of a building close to the seaside. In Mali, the instruments are located in an agronom- ical research station (Station de Recherche Agronomique de Cinzana) of the Institut d'Economie Rurale, $40 \mathrm{~km}$ eastsoutheast of the town of Ségou. In Niger, the station is located in a fallow, $2.5 \mathrm{~km}$ from the village of Banizoumbou, about $60 \mathrm{~km}$ east of the capital Niamey. The instrumentation of the stations is described in detail in Marticorena et al. (2010). In this study, two types of in situ data are used: the dust surface concentration and local meteorological parameters. Atmospheric concentrations of particulate matter smaller than $10 \mu \mathrm{m}\left(\mathrm{PM}_{10}\right)$ are measured using a tapered element oscillating microbalance (TEOM 1400A from Thermo Scientific) equipped with a $\mathrm{PM}_{10}$ inlet. The inlet is located at $6.5 \mathrm{~m}$ height in Mali and Niger and $10 \mathrm{~m}$ in Senegal. The basic meteorological parameters (wind speed and direction, air temperature, relative humidity) are measured with Campbell Scientific instruments. Wind speed and wind direction are measured at $1 \mathrm{~Hz}$ with a 2DWindSonic, temperature and relative humidity using 50Y or HMP50 sensors and rainfall with an ARG100 tipping bucket rain gauge. The data acquisition is made using data logger CR200. Meteorological measurements are made at $\sim 10 \mathrm{~m}$ height in Senegal, $6.5 \mathrm{~m}$ height in Niger and $2.3 \mathrm{~m}$ height in Mali. The PM10 concentrations and the meteorological data are recorded as $5 \mathrm{~min}$ averages. The three stations are equipped with sun photometers from the AERONET/PHOTONS network. The aerosol optical depth (AOD) measured by the sun photometer corresponds to the extinction due to aerosol integrated over the whole atmospheric column. This measurement is thus an indicator of the atmospheric content in optically active particles. Holben et al. (2001) indicate that the uncertainty on the AOD retrieved from AERONET sun photometers in the field was mainly due to calibration uncertainties and estimated the uncertainty at $0.01-0.02$, depending on the wavelength.

\section{Dependency of dust lifting to the representation of wind}

We first present in Fig. 1 the average emission (colored shading) for March 2006 obtained in the SP3 (top) and NP3 (bottom) simulations. The zoomed grid is apparent on the right-hand side of the lower panel from the distortion of the color rectangles, each corresponding to a grid cell. The contours corresponds to the AOD at $550 \mathrm{~nm}$. The NP3 and SP3 emissions are essentially located in the same areas, but they are much stronger for the NP3 simulation. The total Saharan emissions for March 2006 are of $33 \mathrm{Mt}$ for the SP3 and $113 \mathrm{Mt}$ for the NP3 simulation. Even the latter value is in the lower range of current estimates of the climatological total dust emissions by North Africa for March. ${ }^{2}$ As a conse-

\footnotetext{
${ }^{2}$ Marticorena et al. (1997) report values of 163 and $101 \mathrm{Mt}$ for 1990 and 1991 while considering only half of the Sahara. Laurent et al. (2008) compute mean emissions with ERA-40 winds for March (period 1996-2001) of the order of $80 \mathrm{Mt}$ with a maximum value of $205 \mathrm{Mt}$, while Schmechtig et al. (2011) compute emis-
} 

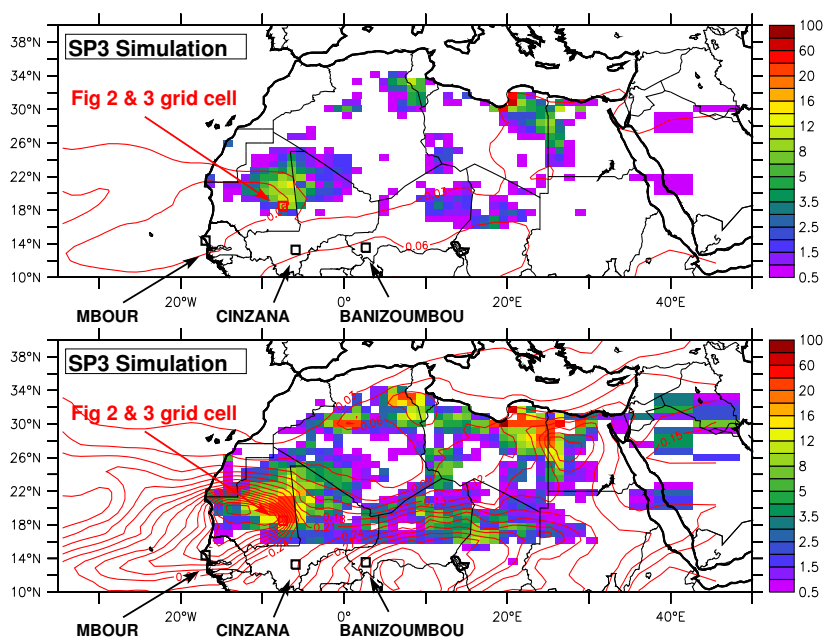

Figure 1. Comparison of the total emission $\left(\mu \mathrm{g} \mathrm{m}^{-2} \mathrm{~s}^{-1}\right)$ for the SP3 (top) and NP3 (bottom) simulations (NP and SP versions of the physical package with $\tau=3 \mathrm{~h}$ for nudging) for March 2006. Contours correspond to the mean AOD at $550 \mathrm{~nm}$, with a 0.02 interval between contours.

quence of the stronger emissions, the AODs for the NP3 are also larger by a factor of about 4 than for the SP3 simulation.

In order to interpret at a process level the origin of the difference in emission between the two simulations, we show in Fig. 2 a scatter plot of the emission and wind intensity for a grid cell in the main emission area in Mauritania (located at $7.5^{\circ} \mathrm{W}, 18.5^{\circ} \mathrm{N}$; shown in red in Fig. 1). We choose this particular point for illustration because it is located in the south of the emission zone, not too far from the latitude at which we show comparisons with in situ wind measurements in the following section. As shown later, the behavior observed at this particular grid point is representative of the whole emission zone. The left panel of the figure corresponds to instantaneous values sampled hourly during the month. The cubic relationship used for emission computation is directly visible on this graph, and the same relationship is clearly exhibited for both simulations although the wind distributions markedly differ. Indeed, the maximum speeds explored by the SP3 simulation never exceed $10 \mathrm{~m} \mathrm{~s}^{-1}$ while the wind distribution for the NP3 simulation includes much larger values.

Considering daily means instead of instantaneous values (right panel of Fig. 2) would have led to the apparently contradictory result that winds are smaller in NP3 than in SP3 but associated with larger dust emissions. It is thus the occurrence of much stronger instantaneous winds at sub-diurnal timescales which explains the larger emissions in NP3.

This is confirmed when focusing on time series of emissions and wind speed at the same grid point for 2 to 13 March (Fig. 3), a period which includes the strongest observed dust

sions of the order of $300 \mathrm{M}$ t for March 2006 with ECMWF forecast winds.
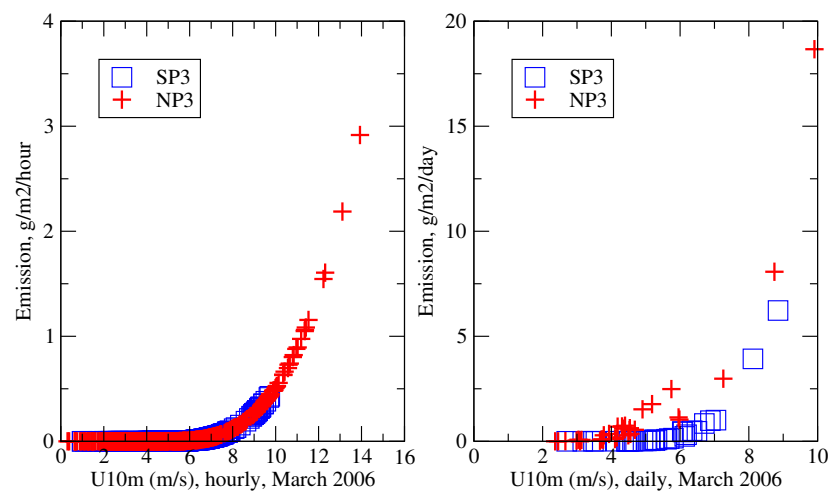

Figure 2. Scatter plot of the emission vs. $10 \mathrm{~m}$ wind speed $\left(\mathrm{m} \mathrm{s}^{-1}\right)$ for simulations SP3 (blue) and NP3 (red) for March 2006, at 7.5 ${ }^{\circ} \mathrm{W}$, $18.5^{\circ} \mathrm{N}$ (location shown in red in Fig. 1). The left panel corresponds to an hourly sampling of instantaneous values (with emission given in $\mathrm{g} \mathrm{m}^{-2} \mathrm{~h}^{-1}$ ) while the right panel shows daily averages (with emissions given in $\mathrm{g} \mathrm{m}^{-2} \mathrm{day}^{-1}$ ).
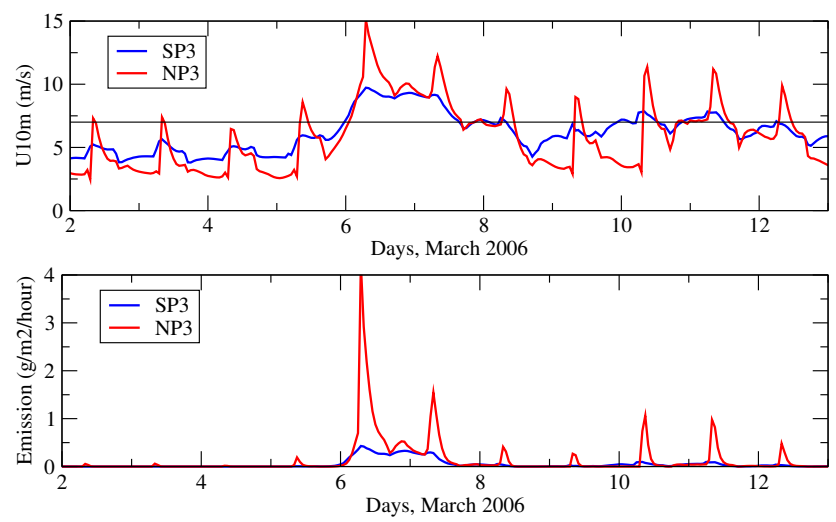

Figure 3. Comparison from 2 to 13 March 2006 of the $10 \mathrm{~m}$ wind (upper panel, $\mathrm{ms}^{-1}$ ) and emissions (lower panel, $\mathrm{g} \mathrm{m}^{-2} \mathrm{~h}^{-1}$ ) for simulations SP3 (blue) and NP3 (red) in the grid cell, selected for emission analysis at $7.5^{\circ} \mathrm{W}, 18.5^{\circ} \mathrm{N}$ (shown in red in Fig. 1). The horizontal line in the upper panel corresponds to a wind of $7 \mathrm{~m} \mathrm{~s}^{-1}$, above which emissions start to be significant.

event of that particular month (Slingo et al., 2006). Thanks to nudging, both simulations follow a similar evolution of the wind at daily scale with a maximum between 6 and 8 March which corresponds to this dust event. However, the NP3 simulation shows a marked peak each morning while the SP3 simulation does not. Because of the strong nonlinearity of the emission process, this morning peak increases emissions during the major dust event and also often produces emissions in the morning when the SP3 simulations does not predict any. 

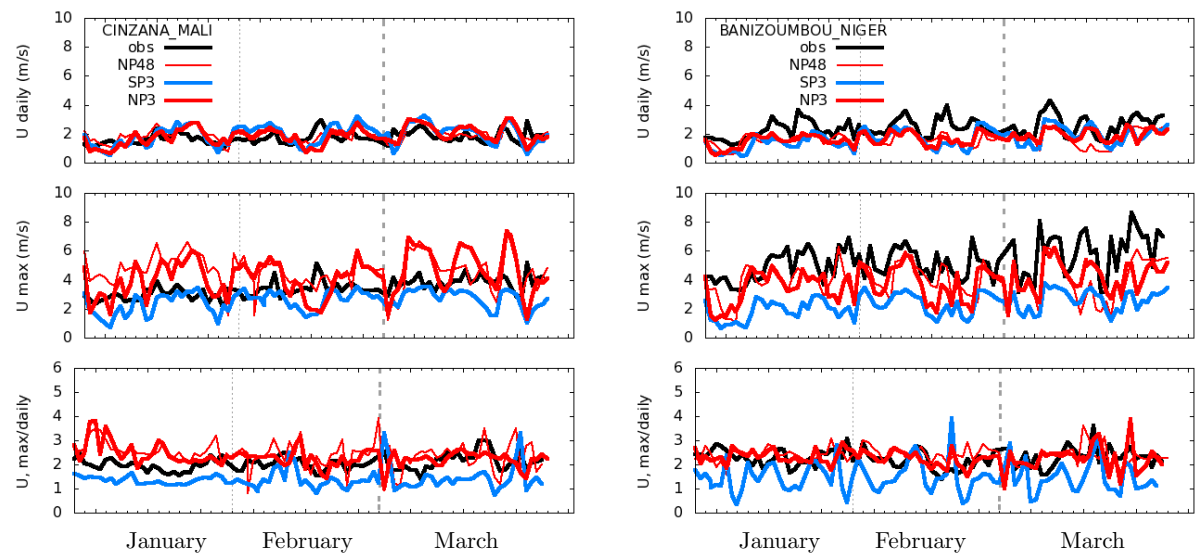

Figure 4. Time evolution over winter 2006 of the daily mean (upper panels) and maximum (middle panels) $10 \mathrm{~m} \mathrm{wind} \mathrm{speed} \mathrm{(m} \mathrm{s}^{-1}$ ) as well as the ratio (lower panels) of the maximum value to the daily mean for Cinzana (left) and Banizoumbou (right). Results of the SP3 (blue), NP3 (thick red line) and NP48 (thin red line) simulations are compared to site observations (black).

\section{Comparison with site observations}

We compare the simulated wind with the available in situ observations described above. We here consider the dry season of 2006, from January to March. The comparison is done for the three simulations: SP3, NP3 and NP48. We show in the top panels of Fig. 4, for Cinzana and Banizoumbou, the evolution of the daily averaged wind. There is a reasonable agreement between models and observations as for the order of magnitude of this mean wind. All the simulations tend, however, to slightly overestimate the wind at Cinzana and underestimate it at Banizoumbou. Differences among the three simulations are generally small. The day-to-day variations of the wind partly follow observations, which illustrates that relevant information at synoptic scales present in ERAI reanalysis are passed to the numerical experiments through the nudging procedure.

The fact that the NP48 simulation does not depart that much from NP3 suggests that nudging with a $48 \mathrm{~h}$ time constant is in fact strong enough to constrain the model day-today variations.

The middle panels in the same figure show the maximum value for each day. Consistent with Fig. 3, the NP version of the model (both NP3 and NP48 simulations) produces much larger maximum winds than the SP version. Those winds are in fact larger than observations at Cinzana (where the SP3 version is closer to observations) and close to observations at Banizoumbou. However, when considering the ratio of the maximum to mean winds, the NP version gives better results for both stations. This ratio ranges from 2 to 2.5 for the NP3 and NP48 simulations and observations compared to 1 to 1.2 for the SP3 simulation. It is shown later that this good agreement is linked more generally to a much better representation of the mean diurnal cycle than in the SP version.

In order to evaluate the dust, we first show in Fig. 5 the comparison of the observed and modeled $\mathrm{PM}_{10}$ surface con-

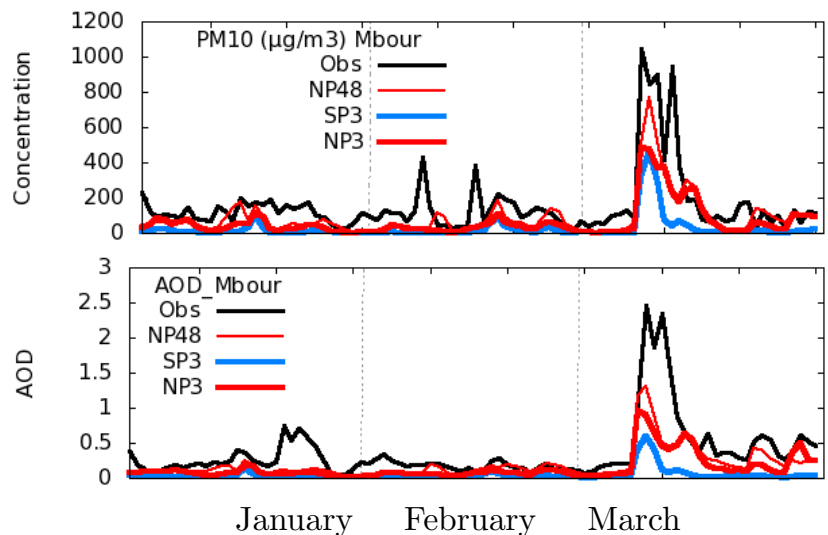

Figure 5. Time evolution over winter 2006 of the daily mean $\mathrm{PM}_{10}$ concentration (top, in $\mu \mathrm{g} \mathrm{kg}^{-1}$ ) and AOD for the M'bour station for simulations SP3 (blue), NP3 (thick red line) and NP48 (thin red line) and for observations (black).

centration and AOD at $550 \mathrm{~nm}$ (computed following Moulin et al., 2001) at M'Bour, close to Dakar/Senegal. This station is considered first because it is downstream of the dust emissions discussed in the previous section. The synoptic behavior is captured reasonably well by the model, in particular the occurrence of the main dust event of the winter in early March. This once again reflects that some information on the actual circulation is transmitted to the simulation thanks to nudging by reanalyses. The concentrations and emissions are, however, typically underestimated by $20-50 \%$ in the NP3 and NP48 simulations, the SP3 simulation being even farther from observations. Note that there is also a significant and systematic increase of dust when weakening the nudging, going from $\tau=3 \mathrm{~h}$ to $48 \mathrm{~h}$.

A more systematic comparison is shown in Fig. 6 for the three stations in form of a scatter plot of observed vs. simu- 

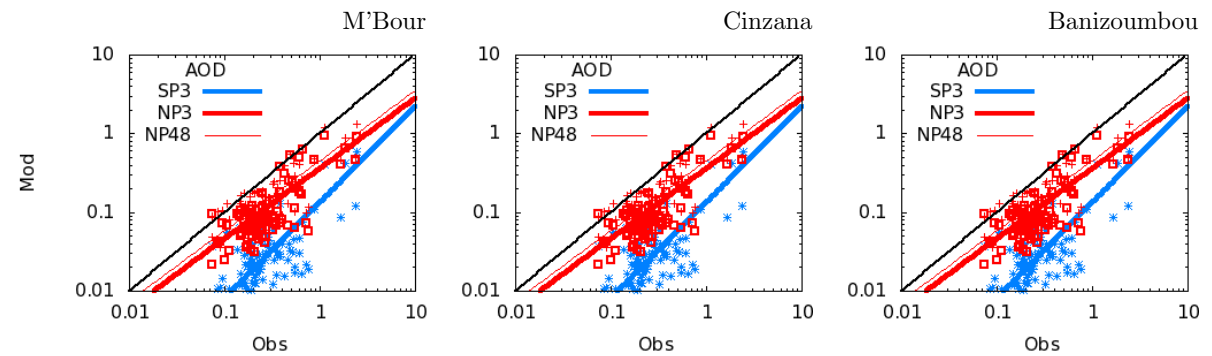

Figure 6. Scatter plots of the model vs. observed AOD at M'bour, Cinzana and Banizoumbou for simulations SP3 (blue), NP3 (thick red line and squares) and NP48 (thin red line and crosses) computed at daily frequency.

lated AOD. The underestimation of AODs is clearly present at the three stations, and it is even somewhat worse at Cinzana and Banizoumbou. The behavior is, however, similar in terms of comparison of the three simulations: AODs are always larger for the NP than for the SP physics and increase when weakening the nudging (from NP3 to NP48). Note that the improvement is significant both for the weak (associated with small lifting events) and strong concentrations.

Several factors can explain the overall underestimations of AODs and concentrations but this discussion is out of the scope of the present paper and will deserve further investigations.

\section{Mean diurnal cycle of boundary layer wind}

Finally, we analyze the representation of the diurnal cycle of wind. We show in Fig. 7 the mean diurnal cycle of the nearsurface wind at Cinzana and Banizoumbou for the full winter period (January to March 2006). Note that this diurnal cycle is very similar whatever the period selected within the winter season for the years 2006 and 2007 considered here. ${ }^{3}$ As was already suggested in Fig. 4, the mean value is somewhat overestimated at Cinzana and underestimated at Banizoumbou for the three LMDZ simulations. The phase and amplitude of the diurnal cycle is, however, much better represented when using the NP rather than the SP version of the model and also better represented than in the reanalyses used for nudging. The rather poor representation of the diurnal cycle of wind in ERAI as well as in other reanalysis data sets was recently pointed out by Largeron et al. (2015).

The tendency of the NP3 and NP48 simulations to overpredict winds at Cinzana and underpredict them at Banizoumbou, already visible in Fig. 4, may have several explanations: effect of local subgrid-scale topography, bad prediction of the local drag which is taken directly from the climate model boundary conditions and not from the more accurate database used to compute emissions or bias in the reanalysis winds

\footnotetext{
${ }^{3}$ The diurnal cycle at M'bour (not shown) displays a similar cycle with maximum in the morning, but not as marked, probably because the land-sea contrasts maintain a significant amount of wind even during the night.
}
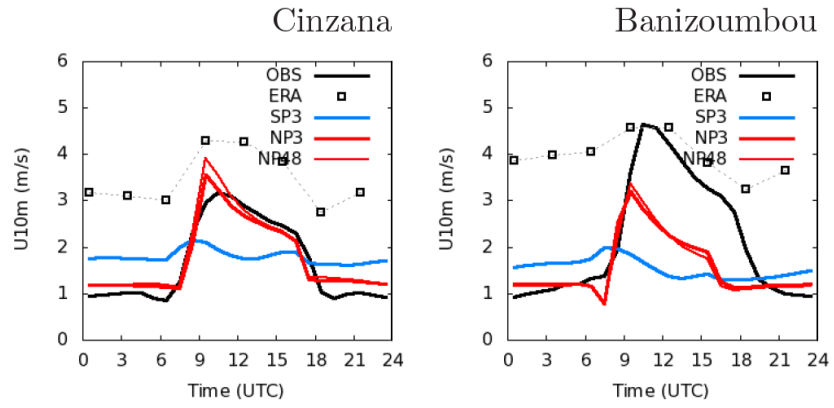

Figure 7. Wind mean diurnal cycle for JFM $2006\left(\mathrm{~m} \mathrm{~s}^{-1}\right)$ for the Cinzana (left) and Banizoumbou (right) stations. Model results (colored curves) are compared to observations (black curve) and ERAI reanalyses (squares) for the same time period. Note that the universal and local times do not depart by more than $1 \mathrm{~h}$ for the region considered here.

used for nudging. Note also that the reanalysis ERAI almost systematically overestimates wind speed for those stations.

The differences seen in Fig. 7 for the $10 \mathrm{~m}$ wind diurnal cycle between simulations and reanalyses reflects strong differences in the vertical, too. We show in Fig. 8 the vertical profiles at 06:00 UTC (left) and noon (right) for Banizoumbou. ${ }^{4}$ At the end of the night, the jet is much stronger in the NP3 and NP48 simulations than in the reanalyses, as is its decoupling from the surface. Note that a similar underestimation of the ERAI low-level jet intensity is shown in Fig. 4 of Fiedler et al. (2013) when compared to observations in the Bodélé region. The wind is much better mixed within the boundary layer at noon in the NP3 and NP48 simulations, while the reanalyses keep the signature of the low-level jet. Note the similarity of the SP version with the reanalysis, which may be related to the fact that both the SP version of LMDZ and the ECMWF model used to produce the reanalysis base their boundary layer computation on eddy diffusion approaches, without accounting for the non-local transport by thermal plumes.

\footnotetext{
${ }^{4}$ The profiles are very similar for Cinzana and not that different for M'Bour (not shown).
} 

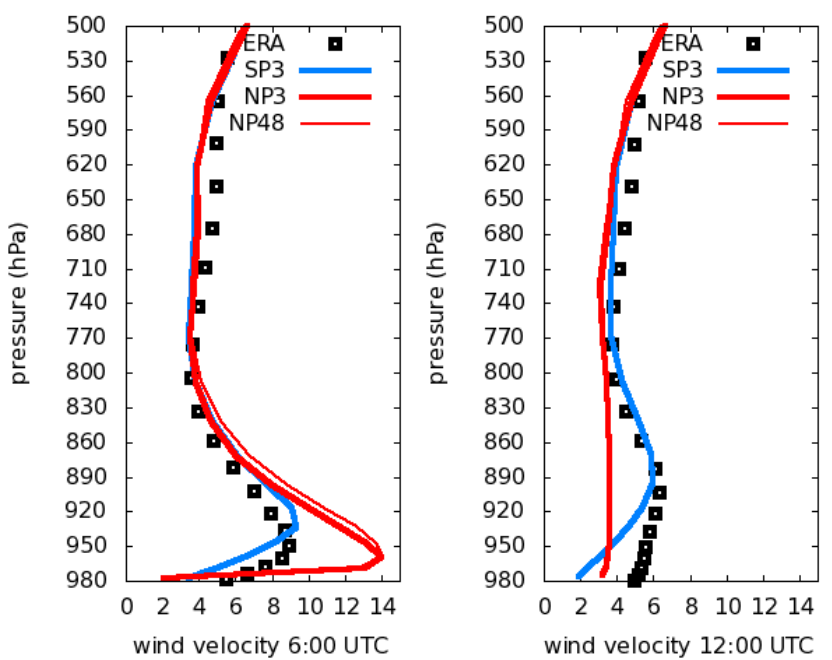

Figure 8. Wind mean vertical profiles $\left(\mathrm{m} \mathrm{s}^{-1}\right)$ for JFM 2006 at 06:00 and 12:00 UTC at Banizoumbou. Model results (colored curves) are compared to ERAI (black squares) for the same time period.

The vertical mixing of horizontal momentum by thermal cells is key for the representation of the nocturnal jet and near-surface wind. We present in the upper panel of Fig. 9, for the NP48 simulation and for 4 consecutive days, the vertical profile of $\|V\|=\sqrt{u^{2}+v^{2}}$ in black contours together with the tendency of this wind module due to the thermal plume model (color shadings):

$\frac{\partial\|V\|}{\partial t}_{\mid \mathrm{th}}=\frac{1}{\|V\|}\left(u{\frac{\partial u}{\partial t}{ }_{\text {th }}}+v \frac{\partial v}{\partial t}{ }_{\mid \mathrm{th}}\right)$.

The top of the turbulent boundary layer is also identified on the graphs as a red curve. Following a classical approach (see, e.g., Hourdin et al., 2002), the curve corresponds to $R i_{\mathrm{b}}=0.25$, where

$R i_{\mathrm{b}}=\frac{g z}{\theta} \frac{\theta-\theta_{\mathrm{s}}}{\|V\|^{2}}$

is a so-called bulk Richardson number (similar to a gradient Richardson number but computed non-locally by replacing gradient terms by finite differences between altitude $z$ with a potential temperature $\theta$ and surface with a temperature $\theta_{\mathrm{s}}$, where the wind is assumed to vanish). During the day, the momentum is well mixed within the full convective boundary layer which grows as high as $5 \mathrm{~km}$, with vertical winds in the thermal plumes of the order of $2 \mathrm{~m} \mathrm{~s}^{-1}$. The collapse of the boundary layer at sunset is very rapid. There is essentially no turbulence left after 18:00. The wind, decoupled from the surface, then starts to accelerate, driven by the imbalance between the Coriolis force and horizontal pressure gradient (which evolves itself in response to the diurnal cycle of the thermal forcing of the monsoon flow; Parker et al., 2005).
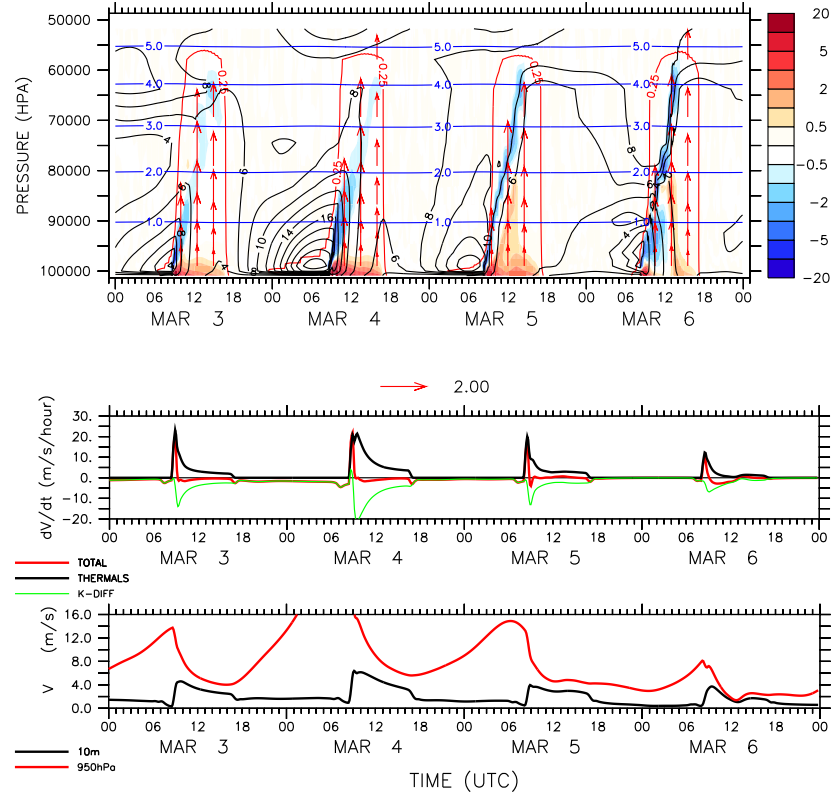

Figure 9. The diurnal cycle of the boundary layer at Banizoumbou over 4 consecutive days in early March 2006 is shown in the upper panel: the vertical distribution of the module of the horizontal wind (black contours, $\mathrm{ms}^{-1}$ ) and the wind module tendency due to vertical transport by the thermal plume model, according to Eq. (7) (colored shades with absolute iso values $0.5,1,2,3,5,10$ and $20 \mathrm{~m} \mathrm{~s}^{-1} \mathrm{~h}^{-1}$ ). The red contour delimits the depth of the boundary layer and corresponds to the 0.25 value of the bulk Richardson number (Eq. 8). The red arrows correspond to the thermal plume velocity in $\mathrm{ms}^{-1}$ (under-sampled with respect to the space-time discretization of the simulation). The vertical axis, in pressure ( $\mathrm{Pa})$, and the altitude (in kilometers, blue contours) are also shown. In the middle panel, we show for the first model layer (located at about $30 \mathrm{~m}$ above surface), the decomposition of the total wind module tendency (TOTAL, red, $\mathrm{m} \mathrm{s}^{-1} \mathrm{~h}^{-1}$ ) as the sum of the thermal plume contribution (THERMAS, black) and turbulent diffusion (K-DIFF, green). The lower panel shows the wind speed at $10 \mathrm{~m}$ (black) and $950 \mathrm{hPa}$ (red), close to the altitude where the nocturnal jet reaches its maximum.

The jet maximum intensity varies from about 8 to $25 \mathrm{~m} \mathrm{~s}^{-1}$ and the height of the jet core from 200 to $500 \mathrm{~m}$ depending on the night considered. The strong wind shear created at the surface gradually produces turbulence in the surface layer, but it is only at sunrise that the boundary layer rapidly develops. The thermal convection starts at 08:30 LT and reaches $1 \mathrm{~km}$ before 10:00 LT. Because the shear in momentum is very strong at the beginning, the impact of vertical transport by the thermal plume model is also very large. The wind speed at surface can accelerate by up to $25 \mathrm{~m} \mathrm{~s}^{-1}$ per hour in the first model layer (middle panel) during a short period (less than $1 \mathrm{~h}$ ). With a typical updraft velocity $w_{\text {th }} \simeq 1 \mathrm{~m} \mathrm{~s}^{-1}$ at the height of the nocturnal jet and an horizontal fraction of the surface covered by thermal plumes $\alpha_{\text {th }}$ of typically 0.1 to 0.2 , the compensating subsidence $\left(10-20 \mathrm{~cm} \mathrm{~s}^{-1}\right.$ typically) 

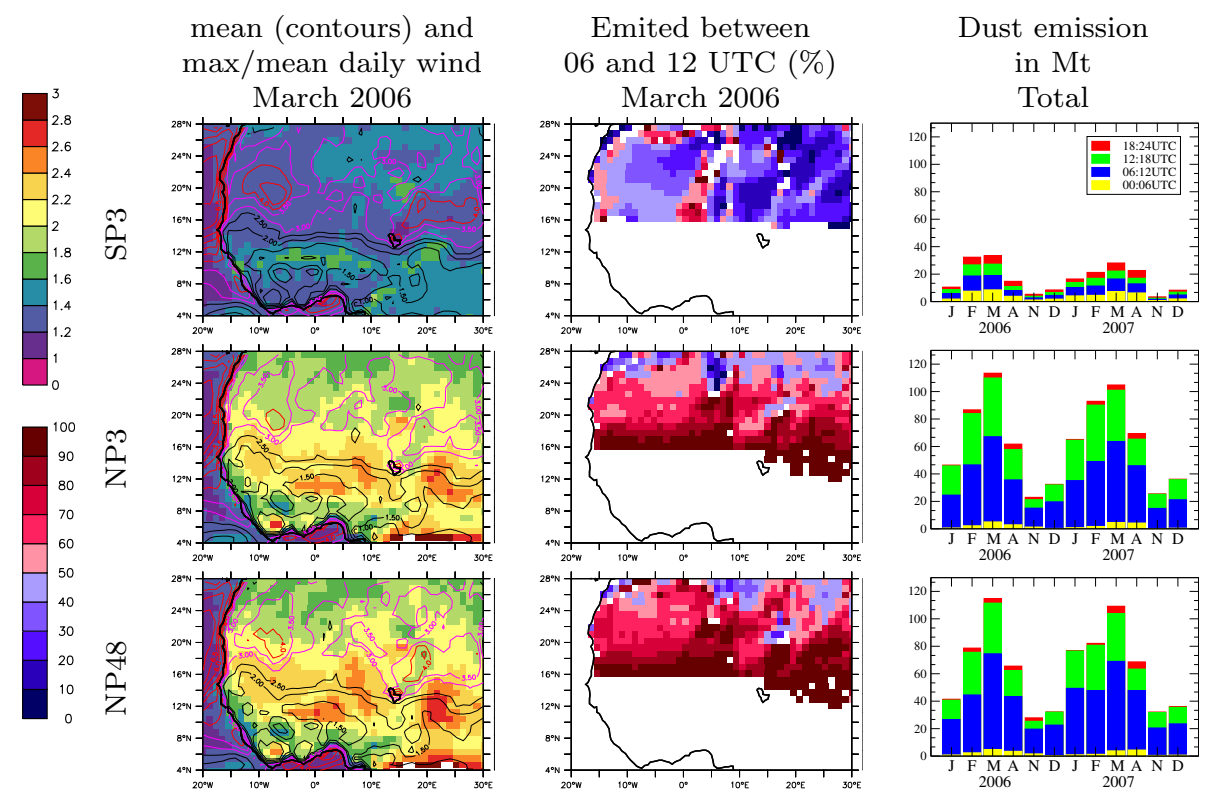

Figure 10. Diurnal cycle of winds and emission for the SP3 (top), NP3 (middle) and NP48 (bottom) simulations. The first two columns correspond to March 2006. The first one displays the mean wind (contours) as well as the monthly mean of the ratio of the daily maximum to averaged wind (color shading). The second column shows the fraction of emission that occurs between 06:00 and 12:00 UTC. The right column shows for the dry-season months of years 2006 and 2005 the total African emission and its distribution between consecutive slots of $6 \mathrm{~h}$ within the day.

needs less than $1 \mathrm{~h}$ to bring the air from the jet core (200$500 \mathrm{~m}$ ) down to the surface.

It is this peak of downward transport from the nocturnal jet which explains the morning peak in near-surface wind. The mixing by thermals also rapidly reduces the jet intensity, reducing in turn the acceleration of surface winds by thermals subsidence. The near-surface wind then decelerates slowly in the afternoon, under the effect of turbulent exchange with the surface. The negative diffusive term (green curve in the second panel of Fig. 9) is almost compensated by the thermal tendency which accounts for convective exchanges between the surface layer and the mixed layer above. Both terms almost cancel after sunset, resulting in a decoupling that allows for the creation of the low-level jet of the following night.

\section{Conclusions}

This study focuses on the impact of the representation of boundary layer processes on near-surface wind and on dust emissions. Significant conclusions may be drawn that are likely to be independent of the particular model used for representation of dust (as soon as it accounts for the strong nonlinearity of emissions to near-surface wind).

1. This study underlines the importance of a correct representation of the vertical transport of horizontal momentum by boundary layer processes for a good representation of the diurnal cycle of wind at the surface.
2. The morning peak of near-surface wind observed almost every day over Sahel is well captured by the NP version of the physical parameterizations. In the model, this peak is due to the rapid downward transport of momentum by the compensating subsidence when the thermal plumes reach the height of the low-level jet which develops during the night at a few hundred meters above the surface.

3. This study advocates for the representation of vertical boundary layer transport through the combination of eddy diffusion and mass flux representation of the coherent structures of the convective boundary layer, an approach first proposed by Chatfield and Brost (1987). It confirms in particular the ability of the so-called thermal plume model to represent in a physical way the vertical transport of momentum, as already illustrated in Fig. 2 of Hourdin et al. (2002), based on a comparison of single-column computations with large eddy simulations results issued from an intercomparison study coordinated by Ayotte et al. (1996).

4. At the Sahelian stations considered here the mean diurnal cycle of the near-surface wind is well captured in the NP version of the LMDZ model that includes these thermal plume processes. It is much better represented in terms of mean value, phase and amplitude than in the reanalyses used for nudging. This conclusion is impor- 
tant for many chemical transport models which rely on reanalyses for the computation of near-surface winds.

5. An important practical consequence of this point is that it could be better to use much larger time constants for nudging than what was currently believed. The rationale for using time constants of a few hours was to let the rapid processes represented in turbulent parameterizations to express themselves, without departing from the observed synoptic situation. The problem is that the time constants which prevail for the creation and control of the nocturnal jet are typically those of the diurnal cycle itself. So constants larger than 1 day should be used for this particular problem. It seems that with time constants as large as $48 \mathrm{~h}$ the synoptic situation is still rather well constrained, which probably points to a reasonable behavior of the physics of the LMDZ model which does not tend to depart too fast from the observed situation. Note that the mean diurnal cycle is almost identical when simulations are conducted without nudging, i.e., in free climate mode (not shown).

Although the detailed analysis of the diurnal cycle of wind was conducted at the stations for which we have observations, located at the south of the emission zone, the same difference among the SP3, NP3 and NP48 simulations is obtained everywhere over the Sahel and Sahara and for all the winter period, as illustrated in Fig. 10. The left panels show, for March 2006, the monthly mean of the ratio of the daily maximum to the daily average of the $10 \mathrm{~m}$ wind. This mean ratio is maximum over Sahel for all simulations. At $12 \mathrm{~N}$, it is typically of 1.6 in SP3 and 2.3 for NP3 and NP48. Over the Sahara, in the main emission zones, it is of the order of 1.3 for SP3 and 1.8 to 2.2 for NP3 and NP48. The ratio is systematically a little bit larger for NP48 than for NP3. The mean wind itself is generally smaller in NP3 than in SP3 and a little bit stronger in NP48 than in NP3.

As a consequence of the different representation of the wind diurnal cycle, a much larger fraction of the dust emissions occurs in the morning between 06:00 and 12:00 UTC in NP3 than in SP3, as seen in the second column of Fig. 10. This fraction is larger than $90 \%$ in the northern part of Sahara and is slightly larger as well in the NP48 than in the NP3 simulation.

This behavior is not specific to this particular month, as can be seen on the third column that shows, for all the dryseason months of years 2006 and 2007, the total emission over Africa split into slots of $6 \mathrm{~h}$. The dominance of morning emissions concerns all the months. This figures can be compared with Fig. 4 of Tegen et al. (2013) that shows that more than $95 \%$ of dust source activation computed from MSG satellite observations occurs between 06:00 and 12:00 UTC.

By cumulating emissions over the 12 months displayed, the total emission is $205 \mathrm{Mt}$ for SP3, 757 for NP3 and 765 for NP48, and the fraction of this emission that occurs between 06:00 and 12:00 UTC is 32,55 and $61 \%$, respectively.
Despite a reasonable representation of the near-surface winds (at least at the stations available, which unfortunately are not in the main emission zones), and the use of a Weibull distribution to account for the effect of spatial inhomogeneities of wind speed within a grid mesh, the model underestimates the observed dust typically by $20-50 \%$ for the NP48 simulation that shows the strongest emissions. The underestimation is similar when considering either AOD or PM10 concentrations. AOD is sensitive to the atmospheric column with a stronger contribution of small particles while the $\mathrm{PM}_{10}$ concentration is a direct measurement of the mass concentration close to the surface. The fact that both indicate a similar underestimation suggests a general underestimation of emissions rather than a size distribution effect.

Such discrepancies are, however, not that exceptional for simulations of African desert dust (e.g., Todd et al., 2008).

This underestimation does not alter the main result of the paper, which is that an accurate representation of the diurnal evolution of the boundary layer and transport of momentum by boundary layer convective cells must be taken into account for a good representation of winds. Such a representation can be obtained through a combination of turbulent diffusion and mass flux parameterization of the boundary layer convection. This study also underlines the importance of in situ long-term and high-frequency meteorological and dust observations for evaluation and improvement of weather forecast and climate models.

Acknowledgements. We thank Bernadette Chatenet, the technical PI of the Sahelian stations from 2006 to 2012, Jean-Louis Rajot, the scientific co-PI, and the African technicians who manage the stations: M. Coulibaly and I. Koné from the Institut d'Economie Rurale in Cinzana, Mali, and A. Maman and A. Zakou from the Institut de Recherche pour le Développement, Niamey, Niger. The work was partially supported by the Escape and Acasis project of the French "Agence Nationale de la Recherche".

Edited by: Y. Balkanski

\section{References}

Alfaro, S. C. and Gomes, L.: Modeling mineral aerosol production by wind erosion: emission intensities and aerosol size distribution in source areas, J. Geophys. Res., 106, 18075-18084, 2001.

Angevine, W. M., Jiang, H., and Mauritsen, T.: Performance of an eddy diffusivity-mass flux scheme for shallow cumulus boundary layers, Mon. Weather Rev., 138, 2895-2912, 2010.

Ayotte, K. W., Sullivan, P. P., Andrén, A., Doney, S. C., Holtslag, A. A., Large, W. G., McWilliams, J. C., Moeng, C.-N., Otte, M. J., Tribbia, J. J., and Wyngaard, J. C.: An evaluation of neutral and convective planetary boundary-layer parameterizations relative to large eddy simulations, Bound.-Lay. Meteorol., 79, 131-175, 1996.

Bain, C. L., Parker, D. J., Taylor, C. M., Kergoat, L., and Guichard, F.: Observations of the Nocturnal Boundary Layer As- 
sociated with the West African Monsoon, Mon. Weather Rev., 138, 3142-3156, doi:10.1175/2010MWR3287.1, 2010.

Beljaars, A. C. M. and Viterbo, P.: The sensitivity of winter evaporation to the formulation of aerodynamic resistance in the ECMWF model, Bound.-Lay. Meteorol., 71, 135-149, doi:10.1007/BF00709223, 1994.

Cakmur, R. V., Miller, R. L., and Torres, O.: Incorporating the effect of small-scale circulations upon dust emission in an atmospheric general circulation model, J. Geophys. Res., 109, D07201, doi:10.1029/2003JD004067, 2004.

Callot, Y., Marticorena, B., and Bergametti, G.: Geomorphologic approach for modelling the surface features of arid environments in a model of dust emissions: application to the Sahara desert, Geodin. Acta., 13, 245-270, doi:10.1016/S09853111(00)01044-5, 2000

Chatfield, R. B. and Brost, R. A.: A two-stream model of the vertical transport of trace species in the convective boundary layer, J. Geophys. Res., 92, 13263-13276, 1987.

Coindreau, O., Hourdin, F., Haeffelin, M., Mathieu, A., and Rio, C.: A global climate model with strechable grid and nudging: a tool for assesment of physical parametrizations, Mon. Weather Rev., 135, 1474-1489, 2007.

Cuesta, J., Marsham, J. H., Parker, D. J., and Flamant, C.: Dynamical mechanisms controlling the vertical redistribution of dust and the thermodynamic structure of the West Saharan atmospheric boundary layer during summer, Atmos. Sci. Lett., 10, 34-42, doi:10.1002/asl.207, 2009.

Deardorff, J. W.: Preliminary results from numerical integrations of the unstable planetary boundary layer, J. Atmos. Sci., 27, 1209$1211,1970$.

Deardorff, J. W.: Theoretical expression for the countergradient vertical heat flux, J. Geophys. Res., 77, 5900-5904, 1972.

Dufresne, J.-L., Foujols, M.-A., Denvil, S., Caubel, A., Marti, O., Aumont, O., Balkanski, Y., Bekki, S., Bellenger, H., Benshila, R., Bony, S., Bopp, L., Braconnot, P., Brockmann, P., Cadule, P., Cheruy, F., Codron, F., Cozic, A., Cugnet, D., de Noblet, N., Duvel, J.-P., Ethé, C., Fairhead, L., Fichefet, T., Flavoni, S., Friedlingstein, P., Grandpeix, J.-Y., Guez, L., Guilyardi, E., Hauglustaine, D., Hourdin, F., Idelkadi, A., Ghattas, J., Joussaume, S., Kageyama, M., Krinner, G., Labetoulle, S., Lahellec, A., Lefebvre, M.-P., Lefevre, F., Levy, C., Li, Z. X., Lloyd, J., Lott, F., Madec, G., Mancip, M., Marchand, M., Masson, S., Meurdesoif, Y., Mignot, J., Musat, I., Parouty, S., Polcher, J., Rio, C., Schulz, M., Swingedouw, D., Szopa, S., Talandier, C., Terray, P., Viovy, N., and Vuichard, N.: Climate change projections using the IPSL-CM5 Earth System Model: from CMIP3 to CMIP5, Clim. Dynam., 40, 2123-2165, doi:10.1007/s00382012-1636-1, 2013.

Engelstaedter, S., Tegen, I., and Washington, R.: North African dust emissions and transport, Earth-Sci. Rev., 79, 73-100, doi:10.1016/j.earscirev.2006.06.004, 2006.

Fiedler, S., Schepanski, K., Heinold, B., Knippertz, P., and Tegen, I.: Climatology of nocturnal low-level jets over North Africa and implications for modeling mineral dust emission, J. Geophys. Res., 118, 6100-6121, doi:10.1002/jgrd.50394, 2013.

Forêt, G., Bergametti, G., Dulac, F., and Menut, L.: An optimized particle size bin scheme for modeling mineral dust aerosol, J. Geophys. Res., 111, D17310, doi:10.1029/2005JD006797, 2006.
Gillette, D. A.: Fine Particulate emissions due to wind erosion, Trans. Am. Soc. Agric. Engrs., 20, 890-987, 2003.

Gounou, A., Guichard, F., and Couvreux, F.: Observations of diurnal cycles over a West African meridional transect: pre-monsoon and full-monsoon seasons, Bound.-Lay. Meteorol., 144, 329357, doi:10.1007/s10546-012-9723-8, 2012.

Gomes, L., Rajot, J. L., Alfaro, S. C., and Gaudichet, A.: Validation of a dust production model from measurements performed in semi-arid agricultural areas of Spain and Niger, Catena, 52, 257-271, doi:10.1016/S0341-8162(03)00017-1, 2003.

Grandpeix, J. and Lafore, J.: A density current parameterization coupled with Emanuel's convection scheme, Part I: The models, J. Atmos. Sci., 67, 881-897, doi:10.1175/2009JAS3044.1, 2010.

Guichard, F., Kergoat, L., Mougin, E., Timouk, F., Baup, F., Hiernaux, P., and Lavenu, F.: Surface thermodynamics and radiative budget in the Sahelian Gourma: Seasonal and diurnal cycles, J. Hydrol., 375, 161-177, doi:10.1016/j.jhydrol.2008.09.007, 2009.

Holben, B. N., Tanre, D., Smirnov, A., Eck, T. F., Slutsker, I., Abuhassan, N., Newcomb, W. W., Schafer, J., Chatenet, B., Lavenu, F., Kaufman, Y., Van de Castle, J., Setzer, A., Markham, B., Clark, D., Frouin, R., Halthore, R., Karnieli, A., O'Neill, N. T., Pietras, C., Pinker, R. T., Voss, K., and Zibordi, G.: An emerging ground-based aerosol climatology: Aerosol Optical Depth from AERONET, J. Geophys. Res., 106, 12067-12098, 2001.

Holtslag, A. A. M. and Boville, B. A.: Local versus non-local boundary-layer diffusion in a global climate model, J. Climate, 6, 1825-1842, 1993.

Hourdin, F., Couvreux, F., and Menut, L.: Parameterisation of the dry convective boundary layer based on a mass flux representation of thermals, J. Atmos. Sci., 59, 1105-1123, 2002.

Hourdin, F., Foujols, M.-A., Codron, F., Guemas, V., Dufresne, J.L., Bony, S., Denvil, S., Guez, L., Lott, F., Ghattas, J., Braconnot, P., Marti, O., Meurdesoif, Y., and Bopp, L.: Impact of the LMDZ atmospheric grid configuration on the climate and sensitivity of the IPSL-CM5A coupled model, Clim. Dynam., 40, 2167-2192, doi:10.1007/s00382-012-1411-3, 2013a.

Hourdin, F., Grandpeix, J.-Y., Rio, C., Bony, S., Jam, A., Cheruy, F., Rochetin, N., Fairhead, L., Idelkadi, A., Musat, I., Dufresne, J.L., Lahellec, A., Lefebvre, M.-P., and Roehrig, R.: LMDZ5B: the atmospheric component of the IPSL climate model with revisited parameterizations for clouds and convection, Clim. Dynam., 40, 2193-2222, doi:10.1007/s00382-012-1343-y, 2013b.

Jam, A., Hourdin, F., Rio, C., and Couvreux, F.: Resolved versus parametrized boundary-layer plumes, Part III: Derivation of a statistical scheme for cumulus clouds, Bound.-Lay. Meteorol., 147, 421-441, doi:10.1007/s10546-012-9789-3, 2013.

Knippertz, P. and Todd, M. C.: Mineral dust aerosols over the Sahara: meteorological controls on emission and transport and implications for modeling, Rev. Geophys., 50, RG1007, doi:10.1029/2011RG000362, 2012.

Laurent, B., Marticorena, B., Bergametti, G., Léon, J. F., and Mahowald, N. M.: Modeling mineral dust emissions from the Sahara desert using new surface properties and soil database, J. Geophys. Res., 113, D14218, doi:10.1029/2007JD009484, 2008.

Largeron, Y., Guichard, F., Bouniol, D., Couvreux, F., Kergoat, L., and Marticorena, B.: Can we use surface wind fields from meteorological reanalyses for Sahelian dust emis- 
sion simulations?, Geophys. Res. Lett., 42, 2490-2499, doi:10.1002/2014GL062938, 2015.

Lothon, M., Saïd, F., Lohou, F., and Campistron, B.: Observation of the diurnal cycle in the low troposphere of West Africa, Mon. Weather Rev., 136, 3477, doi:10.1175/2008MWR2427.1, 2008.

Marticorena, B. and Bergametti, G.: Modeling the atmospheric dust cycle: 1 Design of a soil derived dust production scheme, J. Geophys. Res., 100, 16415-16430, 1995a.

Marticorena, B. and Bergametti, G.: Modeling the atmospheric dust cycle: design of a soil-derived emission scheme, J. Geophys. Res., 102, 16415-16430, 1995b.

Marticorena, B., Bergametti, G., Aumont, B., Callot, Y., N'doumé, C., and Legrand, M.: Modeling the atmospheric dust cycle: 2. Simulation of Saharan dust sources, J. Geophys. Res., 102, 4387-4404, doi:10.1029/96JD02964, 1997.

Marticorena, B., Chatenet, B., Rajot, J. L., Traoré, S., Coulibaly, M., Diallo, A., Koné, I., Maman, A., NDiaye, T., and Zakou, A.: Temporal variability of mineral dust concentrations over West Africa: analyses of a pluriannual monitoring from the AMMA Sahelian Dust Transect, Atmos. Chem. Phys., 10, 8899-8915, doi:10.5194/acp-10-8899-2010, 2010.

Menut, L., Schmechtig, C., and Marticorena, B.: Sensitivity of the sandblasting fluxes calculations to the soil size distribution accuracy, J. Atmos. Ocean. Tech., 22, 1875-1884, 2005.

Menut, L., Foret, G., and Bergametti, G.: Sensitivity of mineral dust concentrations to the model size distribution accuracy, J. Geophys. Res.-Atmos., 112, D10210, doi:10.1029/2006JD007766, 2007.

Menut, L., Chiapello, I., and Moulin, C.: Previsibility of mineral dust concentrations: the CHIMERE-DUST forecast during the first AMMA experiment dry season, J. Geophys. Res., 114, D07202, doi:10.1029/2008JD010523, 2009.

Menut, L., Bessagnet, B., Khvorostyanov, D., Beekmann, M., Blond, N., Colette, A., Coll, I., Curci, G., Foret, G., Hodzic, A., Mailler, S., Meleux, F., Monge, J.-L., Pison, I., Siour, G., Turquety, S., Valari, M., Vautard, R., and Vivanco, M. G.: CHIMERE 2013: a model for regional atmospheric composition modelling, Geosci. Model Dev., 6, 981-1028, doi:10.5194/gmd6-981-2013, 2013.

Moulin, C., Gordon, H. R., Banzon, V. F., and Evans, R. H.: Assessment of Saharan dust absorption in the visible from SeaWiFS imagery, J. Geophys. Res., 106, 18239, doi:10.1029/2000JD900812, 2001.

Neggers, R. A. J.: A dual mass flux framework for boundary layer convection, Part II: Clouds, J. Atmos. Sci., 66, 1489-1506, 2009.

Neggers, R. A. J., Köhler, M., and Beljaars, A. C. M.: A dual mass flux framework for boundary layer convection. Part I: Transport, J. Atmos. Sci., 66, 1465, doi:10.1175/2008JAS2635.1, 2009.

Nickling, W. G. and Gillies, J. A.: Emission of fine-grained particulates from desert soils, in Paleoclimatology and Paleometeorology: Modern and Past Patterns of Global Atmospheric Transport, edited by: Leinen, M. and Sarnthein, M., Kluwer Academic Publ., Dordrecht, 133-165, 1989.

Nickling, W. G. and Gillies, J. A.: Dust emission and transport in Mali, West Africa, Sedimentology, 40, 859-868, 1993.

Parker, D. J., Burton, R. R., Diongue-Niang, A., Ellis, R. J., Felton, M., Taylor, C. M., Thorncroft, C. D., Bessemoulin, P., and Tompkins, A. M.: The diurnal cycle of the West African monsoon circulation, Q. J. Roy. Meteor. Soc., 131, 2839-2860, doi:10.1256/qj.04.52, 2005.

Pergaud, J., Masson, V., Malardel, S., and Couvreux, F.: A parameterization of dry thermals and shallow cumuli for mesoscale numerical weather prediction, Bound.-Lay. Meteorol., 132, 83106, doi:10.1007/s10546-009-9388-0, 2009.

Rajot, J. L., Alfaro, S. C., Gomes, L., and Gaudichet, A.: Soil crusting on sandy soils and its influence on wind erosion, Catena, 53, 1-16, 2003.

Redelsperger, J.-L., Thorncroft, C. D., Diedhiou, A., Lebel, T., Parker, D. J., and Polcher, J.: African monsoon multidisciplinary analysis: an international research project and field campaign, B. Am. Meteorol. Soc., 87, 1739-1746, doi:10.1175/BAMS-87-121739, 2006.

Rio, C. and Hourdin, F.: A thermal plume model for the convective boundary layer: representation of cumulus clouds, J. Atmos. Sci., 65, 407-425, 2008.

Rio, C., Hourdin, F., Grandpeix, J., and Lafore, J.: Shifting the diurnal cycle of parameterized deep convection over land, Geophys. Res. Lett., 36, L07809, doi:10.1029/2008GL036779, 2009.

Rio, C., Hourdin, F., Couvreux, F., and Jam, A.: Resolved versus parametrized boundary-layer plumes, Part II: Continuous formulations of mixing rates for mass-flux schemes, Bound.-Lay. Meteorol., 135, 469-483, doi:10.1007/s10546-010-9478-z, 2010.

Schepanski, K., Tegen, I., Todd, M. C., Heinold, B., BöNisch, G., Laurent, B., and Macke, A.: Meteorological processes forcing Saharan dust emission inferred from MSG-SEVIRI observations of subdaily dust source activation and numerical models, J. Geophys. Res.-Atmos., 114, D10201, doi:10.1029/2008JD010325, 2009.

Schmechtig, C., Marticorena, B., Chatenet, B., Bergametti, G., Rajot, J. L., and Coman, A.: Simulation of the mineral dust content over Western Africa from the event to the annual scale with the CHIMERE-DUST model, Atmos. Chem. Phys., 11, 7185-7207, doi:10.5194/acp-11-7185-2011, 2011.

Seinfeld, J. H. and Pandis, S. N. (Eds.): Atmospheric Chemistry and Physics: From Air Pollution to Climate Change, in: Atmospheric chemistry and physics: from air pollution to climate change, New York, NY: Wiley, 1998 Physical description: xxvii, 1326 pp., Wiley-Interscience Publication, ISBN: 0471178152, 1998.

Shao, Y. and Lu, I.: A simple expression for wind erosion threshold friction velocity, J. Geophys. Res., 105, 22437-22443, 2000.

Shao, Y., Ishizuka, M., Mikami, M., and Leys, J. F.: Parameterization of size-resolved dust emission and validation with measurements, J. Geophys. Res., 116, D08203, doi:10.1029/2010JD014527, 2011.

Siebesma, A. P., Soares, P. M. M., and Teixeira, J.: A combined eddy-diffusivity mass-flux approach for the convective boundary layer, J. Atmos. Sci., 64, 1230, doi:10.1175/JAS3888.1, 2007.

Slingo, A., Ackerman, T. P., Allan, R. P., Kassianov, E. I., McFarlane, S. A., Robinson, G. J., Barnard, J. C., Miller, M. A., Harries, J. E., Russell, J. E., and Dewitte, S.: Observations of the impact of a major Saharan dust storm on the atmospheric radiation balance, Geophys. Res. Lett., 33, L24817, doi:10.1029/2006GL027869, 2006.

Soares, P. M. M., Miranda, P. M. A., Siebesma, A. P., and Teixeira, J.: An eddy-diffusivity/mass-flux parametrization for dry and shallow cumulus convection, Q. J. Roy. Meteor. Soc., 130, 3365-3383, 2004. 
Solmon, F., Mallet, M., Elguindi, N., Giorgi, F., Zakey, A., and Konaré, A.: Dust aerosol impact on regional precipitation over western Africa, mechanisms and sensitivity to absorption properties, Geophys. Res. Lett., 35, L24705, doi:10.1029/2008GL035900, 2008.

Sow, M., Alfaro, S. C., Rajot, J. L., and Marticorena, B.: Size resolved dust emission fluxes measured in Niger during 3 dust storms of the AMMA experiment, Atmos. Chem. Phys., 9, 38813891, doi:10.5194/acp-9-3881-2009, 2009.

Spyrou, C., Kallos, G., Mitsakou, C., Athanasiadis, P., Kalogeri, C., and Iacono, M. J.: Modeling the radiative effects of desert dust on weather and regional climate, Atmos. Chem. Phys., 13, 54895504, doi:10.5194/acp-13-5489-2013, 2013.

Stull, R. B.: Transilient turbulence theory, Part I: The concept of eddy-mixing across finite distances, J. Atmos. Sci., 41, 33513367, 1984.

Taylor, K. E., Stouffer, R. J., and Meehl, G. A.: An overview of CMIP5 and the experiment design, B. Am. Meteorol. Soc., 93, 485-498, doi:10.1175/BAMS-D-11-00094.1, 2012.

Tegen, I., Schepanski, K., and Heinold, B.: Comparing two years of Saharan dust source activation obtained by regional modelling and satellite observations, Atmos. Chem. Phys., 13, 2381-2390, doi:10.5194/acp-13-2381-2013, 2013.
Tiedtke, M.: A comprehensive mass flux scheme for cumulus parameterization in large-scale models, Mon. Weather Rev., 117, 1179-1800, 1989.

Todd, M. C., Bou Karam, D., Cavazos, C., Bouet, C., Heinold, B., Baldasano, J. M., Cautenet, G., Koren, I., Perez, C., Solmon, F., Tegen, I., Tulet, P., Washington, R., and Zakey, A.: Quantifying uncertainty in estimates of mineral dust flux: an intercomparison of model performance over the Bodélé Depression, northern Chad, J. Geophys. Res.-Atmos., 113, D24107, doi:10.1029/2008JD010476, 2008.

Troen, I. and Mahrt, L.: A simple model of the atmospheric boundary layer: sensitivity to surface evaporation, Bound.-Lay. Meteorol., 37, 129-148, 1986.

Yamada, T.: Simulations of nocturnal drainage flows by a $q^{2} l$ turbulence closure model, J. Atmos. Sci., 40, 91-106, 1983.

Yoshioka, M., Mahowald, N. M., Conley, A. J., Collins, W. D., Fillmore, D. W., Zender, C. S., and Coleman, D. B.: Impact of desert dust radiative forcing on sahel precipitation: relative importance of dust compared to sea surface temperature variations, vegetation changes, and greenhouse gas warming, J. Climate, 20, 1445, doi:10.1175/JCLI4056.1, 2007. 